胃の平滑筋芽細胞腫の 1 例

\begin{tabular}{lllllll}
\multicolumn{8}{c}{ 東大阪市立中央病院外科 } & & \\
明石 & 章則 & 飯尾 & 雅彦 & 吉川 幸伸 & 伊藤 & 則幸 \\
中島 & 信一 & 杉野 & 盛規 & 南 俊之介 & &
\end{tabular}

\title{
A CASE OF LEIOMYOBLASTOMA OF THE STOMACH
}

\author{
Akinori AKASHI, Masahiko IIO, Yukinobu YOSHIKAWA, \\ Noriyuki ITO, Shinichi NAKASHIMA, Seiki SUGINO \\ and Shunnosuke MINAMI \\ Department of Surgery, Higashiosaka City Hospital
}

卖引用語：胃平滑筋芽細胞腫

I.はじめに

1962年 Stout ${ }^{11}$ は胃筋原性腫煌のうち, 平滑筋腫ある いは平滑筋肉腫とも異なる特徵的な病理組織像を呈す る69例を検討し，これを bizarre leiomyoblastoma と 命名した. その後同様の症例が次第に報告されるよう になり, 本邦では1965年久保2)が報告して以来, 100例3) 近くの報告がみられる，最近，われわれは本人の希望 により経過観察中であった胃体中部粘膜下腫瘤疑いの 症例がたまたま 3 回目の胃生検で低分化腺癌の疑診を 受けたため胃切除施行. 術後の病理組織学的検查によ り胃平滑筋芽細胞腫と診断された 1 例を経験したの で，文献的考察を加えて報告する。

\section{II. 症 例}

患者：65歳, 女性.

主訴：全身倦怠感。

既往歴：45歳時, 子宮筋腫で子宫䐋上部切断術, 55 歳時, 右腎結石で結石除去術を受けた。

家族歴：特記すべきことなし。

現病歴：1982年 2 月, 全身僚意感のために精查を希 望して当院を受診した。

上部消化管造影所見：図 1 のごとく，胃体中部後壁 大弯側寄りに大きさ $20 \times 30 \mathrm{~mm}$, 辺縁明瞭で表面平滑 な，汪淰円形の陰影欠損像が認められた。

胃内視鏡所見：1982年 3 月に施行した。胃体中部後 壁大弯側寄りに大きさ $25 \times 15 \times 10 \mathrm{~mm}$, 表面平滑な隆

$<1984$ 年10月17日受理 >別刷請求先：明石 章則 干 577 東大阪市御㴻南 $2-3-1$ 東大阪市立中央 病院外科
図 1 上部消化管造影像

胃体中部に表面平滑な円形の陰影がみられる。

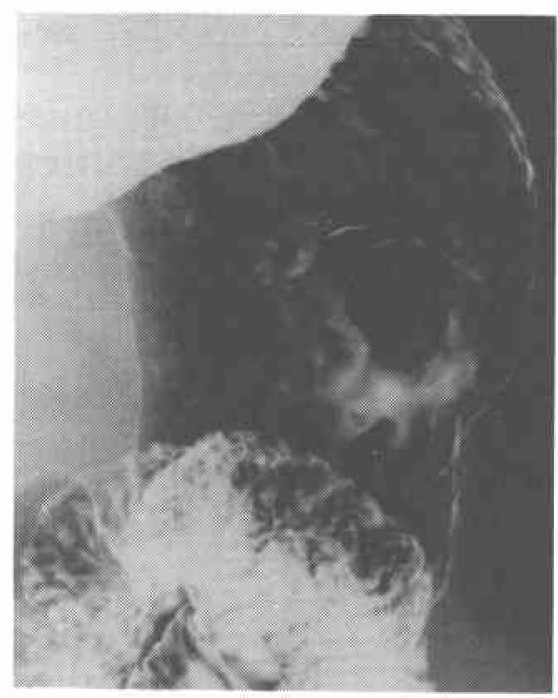

起性病変が認められた，基部のくびれはなく，隆起性 病変の表面は正常粘膜で扮括われていた(図 2). 隆起 性病変表面より 4 個の組織片を採取したが, 胃癌取り 扱い規約に依るといずれもGroup 1であった。半年後 に2 回目の胃内視鏡検査を怙こない, その時の生検も Group 1であった. さらに半年後の1983年 3 月に 3 回 目の胃内視鏡検査を施行した。隆起性病変の大ささ, 性状に変化は認められなかったが, 生検では poorly differentiated adenocarcinomaの診断を得たため手 術目的で当科に入院した. 
図 2 胃内視鏡

胃体中部に $25 \times 15 \times 10 \mathrm{~mm}$, 表面平滑な隆起性病 変を認める。

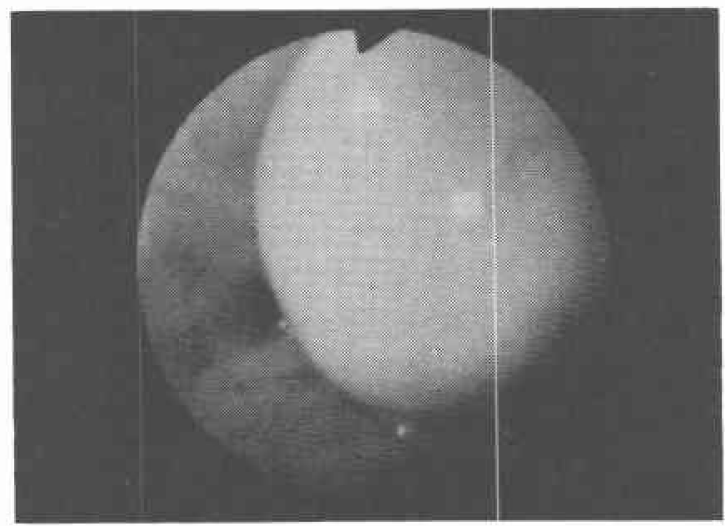

入院時現症：体格・栄養ともに中等度. 眼䀫結膜に 貧血なく，眼球結膜に黄染なし，胸部理学的所見に著 変はなかった。腹部は右側腹部と下腹部中央に手術洀 痕を認める以外に異常を認めなかった。

入院時検査成績: 赤血球数 $411 \times 10^{4} / \mathrm{mm}^{3}$, 血色素量 $13.7 \mathrm{~g} / \mathrm{dl}, \mathrm{Ht}$ 值 $39 \%$, 白血球数 $4,800 / \mathrm{mm}^{3}$ であった. 便潜血でオルトトリジン（十）グアヤック（微）を認 める以外に生化学検査, 尿検査, 胸部 X線等に異常を 認めなかった（表 1 ）。

腹部 CT 所見：腫瘤は胃壁より連続して胃壁外性に 発育していた。内部には石灰化陰影々:中心壊死部之考 えられる low density 部が認められた（図３）。

平滑筋肉腫を疑う症例であるが，胃生検の結果より

表 1 入院時検査成績

\begin{tabular}{|c|c|c|c|}
\hline \multirow{2}{*}{$\begin{array}{c}\text { 一般㭘血. } \\
\text { RBC. }\end{array}$} & \multicolumn{3}{|c|}{ 腎機能。 } \\
\hline & $411 \times 10^{4} / \mathrm{mm}^{3}$ & BUN. & $17 \mathrm{mg} / \mathrm{dl}$ \\
\hline $\mathrm{Hb}$. & $13.7 \mathrm{~g} / \mathrm{dl}$. & Creatinine. & $1.1 \mathrm{mg} / \mathrm{dl}$ \\
\hline Ht. & $39 \%$ & 検尿. & \\
\hline WBC. & $4,800 / \mathrm{mm}^{3}$ & 糖. & 陰性. \\
\hline Plt. & $27.4 \times 10^{4} / \mathrm{mm}^{3}$ & 蛋白. & 陰性. \\
\hline 血清電解質. & & 沈渣. & 正常. \\
\hline 異常なし. & & 便潜血. & \\
\hline 肝機能. & & $\mathrm{O}-\mathrm{T}$ & $(+)$ \\
\hline T.P. & $6.7 \mathrm{~g} / \mathrm{dl}$ & G. & （微）。 \\
\hline Alb. & $4.4 \mathrm{~g} / \mathrm{dl}$ & CEA. & $0.57 \mathrm{ng} / \mathrm{ml}$ \\
\hline T-Bil. & $1.0 \mathrm{mg} / \mathrm{dl}$ & AFP. & $5.0 \mathrm{ng} / \mathrm{ml}$ \\
\hline GOT. & $16 \mathrm{U}$ & 心電図. & 正常. \\
\hline GPT. & $16 \mathrm{U}$ & 胸部し線鼠。 & 正常. \\
\hline ALP. & $5.4 \mathrm{~K}-\mathrm{AU}$ & & \\
\hline ZTT. & $11 \mathrm{U}$ & & \\
\hline TTT. & $1 \mathrm{U}$ & & \\
\hline
\end{tabular}

図 3 腹部 CT 像

腫瘤陰影（矢印）は胃壁より壁外性に発育してい た.

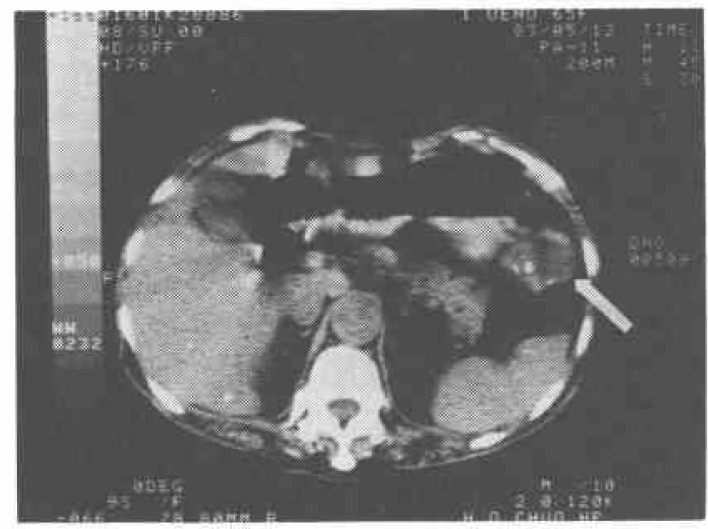

一応胃癌として1983年 5 月に手術を施行した。

手術所見：上腹部正中切開で開腹した。腹水なく, 肝・腪への転移や腹膜播種は認めなかった，網亳内に， 胃体部後壁大弯側から壁外性に発育した鶏卵大, 表面 平滑, 弾性軟の腫瘤を認めた。腫瘤は大網と癒着して 拈り，胃癌取り扱い規約に依るとリンパ節腫脹はNo. $1,4,5,6,8$ にみられた。幽門側普通胃切除術とリンパ 節郭清 $\left(\mathrm{R}_{2}\right)$ を施行した。

切除標本所見：図 4 のごとく腫瘤は胃体部後壁大弯 側から壁外性に発育し, 大きさ $6.5 \times 3.8 \times 3.8 \mathrm{~cm}$, 弾性 軟で一部波動を認めた，胃を小弯側で切開すると，胃 体部後壁にクルミ大の粘膜下腫瘤を認め, その粘膜面 は潰瘍形成がなかった。腫瘤の割面は充実性部分と多

図 4 切除標本

大きさ $6.5 \times 3.8 \times 3.8 \mathrm{~cm}$ 弾性軟で, 胃体部後壁よ り壁外性に発育している.

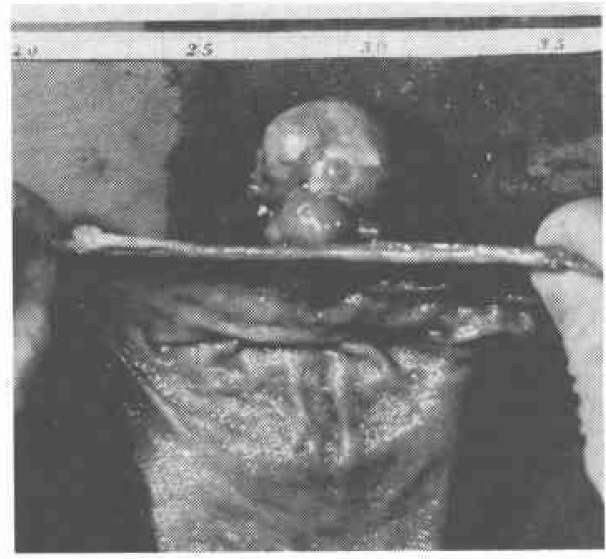




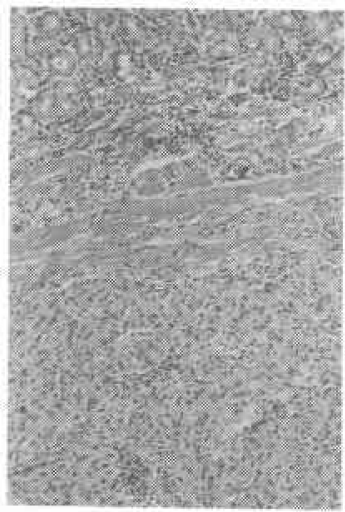

(a)

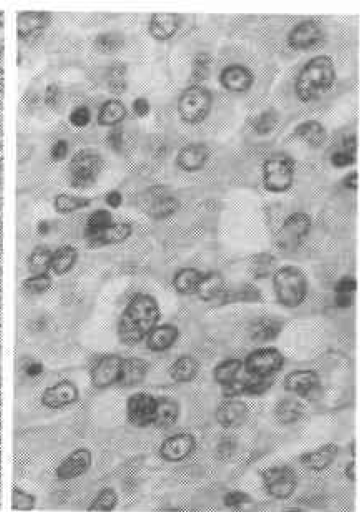

(b)
図 5 摘出標本の組織像 (a. $\mathrm{HE} \times 100$, b. HE $\times 400)$ 胃粘膜下に，核周囲に淡明な胞体を有する細胞や 紡釷形の腫汮細胞がみられる。

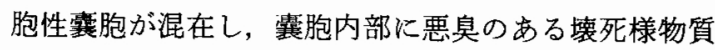
を充満させていた。

病理組織学的所見：胃粘膜下に紡錘形の腫瘍細胞が 束状に交錯した部位や，円形または多角形の細胞で核 周团に淡明な胞体を有する細胞が存在して打り，平滑 筋芽細胞腫と診断された(図 5 )。な招りンパ節の転移 はなかった。すた，術前の胃内視鏡検査での生検組織 は poorly differentiated adenocarcinomaであった が, 再検討の結果, 平滑筋芽細胞腫と訂正された。

術後16カ月を経た現在も再発の微候なく健在であ る。

\section{III. 考 察}

1962年 Stout ${ }^{1)}$ が円形細胞で核周囲に透明体がみら れる特異な細胞形態をとる胃の平滑筋肉腫69例を総括 して平滑筋芽細胞腫と名付けて以来この名称が用いら れている. 本邦では, 1965年久保 ${ }^{2} か ゙$ 胃の变形平滑筋芽 細胞腫として報告をして以来, 同様の報告がみられる ようになった。

本腫瘍の病理組織像の特徵は, Stout ${ }^{11}$ とると円形 あるいは多角形の好酸性細胞が多数を占め, 核を取り 囲むように透明体があってこの透明体の存在が平滑筋 芽細胞腫の診断に重要であると報告している.しかし， この透明体はホルマリン固定時の人工産物ではないか という意見がある。今村らかの電顕的観察で，この透明 体は腫瘍細胞内の粗面小胞体の拡張や大空胞のためで あり, 透明体の存在も否定していない。

本腫湯の発生起源として，大多数は平滑筋由来を支 持しているが，今村ら4)や田中ら5) は電顕により par- aganglioma 由来, Eimoto ${ }^{6}$ は血管壁周細胞起源とし ているなどまだ意見の一致をみず今後の研究成果を待 たねばならない。

症状は海法ら7の76例の集計によると，記載の明ら かな66例では負血・吐下血が24例（36\%）之出血症状 を訴える例が多く，次に腹痛23例 (34\%) で，無症状 だが精査，集検で発見されたものが10例(15\%)になっ ている. 自験例は胃腸症状がなく本人の精査希望で偶 然発見されたものである，腫瘤が発育するに従い，腹 痛または漬瘍形成で出血症状が出現してくるものと予 想される。

本腫瘍の術前診断は困難である，江崎ら ${ }^{37}$ は胃平滑 筋芽細胞腫と術前に診断乙兄た症例は77例中 8 例 (10\%) で, 半数以上の 41 例 $(53.2 \%)$ が粘膜下畽場の 診断にとどまっていると報告している，術前に平滑筋 芽細胞腫と診断可能だった 8 例のうち， 5 例が生検に て, 2 例が高周波凝固生検で確定診断なされており, 残り 1 例が動脈造影で疑診とされた。

本腫煌の術前診断は, 粘膜下腫湟表面に潰煬形成を 認める場合には生検に基づく病理組織診断が可能な時 がある，術前に生検で診断可能だった 5 例はすべて粘 膜下腫瘍表面に潰瘍を形成していた。本腫瘍は胃粘膜 に漬湯を形成する場合が多く，海法7》 566 例中 35 例 (62.5\%), Abramson ${ }^{81}$ は95例中49例 (51.6\%) に認め られたと報告している。しかし，腫煌表面に变化のな い症例についての術前診断は困難である. 高周波凝固 生検で確定診断がなされた 2 例，すなわち吉田ら9や 東ら ${ }^{10}$ は潰瘍を伴わない胃粘膜下腫瘍に対して高周波 電流 $(100 \sim 150 \mathrm{~mA})$ の応用で粘膜下腫場表面に凝固部 を作り，粘膜欠損または浅い潰場を形成させ腫湯組織 片を採取す方法を工夫している，自験例は潰場形成を 伴わないが術前に腫場組織片の採取が可能だったのは 粘膜下腫堭の生長による粘膜の菲薄化のためと予想さ れる。をた, 診断法としての動脈造影は, 本腫煌が筋 原性腫瘍として血管に富むため腫瘍影が濃染されるこ とから Wolf ${ }^{11}$ む有用としているが, 異常所見のない場

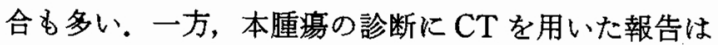
鬼束 ${ }^{12)}$ や加納ら ${ }^{13)}$ があるが, 自験例同様に腫瘍は enhance される傾向が強く，中心壊死部は low density を示す。

本腫瘍の大多数は良性の経過をたどるが，海法ら7 によれば76例中 7 例 $(9.2 \%)$ に転移や直接漫潤がみら

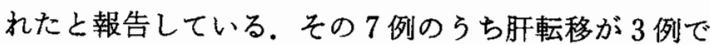
らち 1 例は肺・腹膜へす転移していた。リンパ節転移 
が 2 例, 腸間膜転移, 脾への直接漫潤が、各 1 例づつで あった。また，Abramson ${ }^{8)}$ は転移率 $12 \%$ ， Pizzimbone $^{14)} 4.1 \%$ としてい.

悪性度を推測する指標として Stout ${ }^{11}$ は mitotic rate に注目し，69例中 2 例にリンパ節転移・肝転移が みられ，その 2 例とも50視野中 $(\times 200) 10$ 個以上の核 分裂像が認められたと報告している. また, Appelman ら 15$)$ も核分裂像が50視野中 $(\times 300) 10$ 個以上で転移率 $100 \% ， 1 \sim 5$ 個で13\%と報告している.乙かし， mitotic rate と悪性度とが相関しなかった例も報告さ れて招り, 福本ら ${ }^{16)}$ は肝転移例でる高倍率50視野中に 核分裂は汪とんど認められなかったとしている。この ように悪性度の判定には mitotic rate の数や浸潤像は 重要であるが，これらのみでは充分に判定できるとは 考えにくい.

治療は外科的切除がひろく括こなわれている，O' Brien $^{17)}$ や Appelman ${ }^{15)}$ は楔状切除で良いとしている が，本邦ではほとんど胃切除が行われ，リンパ節郭清 を加壳ている報告が多い。海法ら”は76例中 2 例, Stout ${ }^{1}$ は69例中 2 例のリンパ節転移をみており，リン パ節郭清も付加すべきと思われる。

\section{IV. 結 語}

胃平滑筋芽細胞腫の 1 例を経験したので, 若干の文 献的考察を加えて報告した。

\section{文献}

1) Stout AP: Bizarre smooth muscle tumors of the stomach. Cancer 15:400-409, 1962

2）久保俊夫, 中尾 清, 原沢高義：胃の変形平滑筋芽 細胞腫 (Bizarre leiomyoblastoma). 癌の臨 $11: 643-646,1965$

3）江崎友通, 中谷勝紀, 宮城信行结：胃の leiomyoblastoma の 1 治駼例と本邦における 96 例の文献的考察. 臨外 $37: 1713-1718,1982$

4) 今村正克：胃の bizarre leiomyoma (ledtmyob- lastoma）の電顕的観察. 癌の臨 $20: 472,1974$

5）田中貞夫, 坂江清弘, 徳永正義注か：胃の所謂変型 平滑筋芽細胞脜 (bizarre leiomyoblastoma) の病 理組織学的研究. 鹿児島大医誌 $25: 283-298$, 1974

6) Eimoto T, Miyake M, Sasaki T: Vascular leimyoblastoma of the stomach; observations nupporting its origin from Zimmermann's pericyte. Acta Pathol Epn $29: 277-288,1979$

7）海法恒夫, 松本 繁,鈴木清夫结か：巨大な胃平滑 筋芽細胞曍の 1 例一本邦報告76例の検討一. 日臨 外医会誌 $43418-427,1982$

8) Abramson DJ : Leiomyosarcoma of the stomach. Surg Gynecol Obstet 136:118-125, 1973

9）吉田隆兑, 黒木 健, 渡辺英伸：胃粘膜下腫瑒の高 周波凝固に基づく生検診断の試み. 胃と腸 10 : 1385-1393, 1975

10）東 秀一, 田中隆次, 坂本惇夫ほか：胃平滑筋芽細 胞腫の 2 例. 日消病会誌 $75: 98,1978$

11) Wolf JS: Massive leiomyoblastoma of the stomach. Arch Surg $96: 284-288,1968$

12）鬼束惇義, 乾 博史, 後藤明彦ほか：腹部腫瘤を主 症状とした胃の壁外性 bizarre leiomyoblastoma の 1 例。胃と腸 $15: 1057-1061,1980$

13）加納宣康, 鬼束嵉義, 後藤明彦ほか：胃 bizarre leiomyoblastoma の 1 例. 外科治療 49: $120-123,1983$

14) Pizzimbono CA, Higa E, Wise L: Leionyoblastoma of the lesser nac: Case report and review of the literature. Am Surg 39 : 692-699, 1973

15) Appelman HD, Helwig EB: Gastric epitherioid leiomyoma and leiomyosarcoma (leiomyoblastoma). Cancer 38:708-728, 1976

16）福本陽平：肝臟に転移した胃 leiomyoblastoma の1 剖検例. 日消病会誌 $75: 1290,1978$

17) O'Brien SE, Shier KJ: Leiomyoblastoma of the stomach. Can J Surg 17:105-110, 1974 